\title{
Phytoremediation Potential of Crotalaria juncea Plants in Lead-Contaminated Soils
}

\author{
Tatyane Martins Silva ${ }^{1}$, Gabriela de Medeiros Macêdo ${ }^{1}$, Nathalia Zenaide Duraes Soares ${ }^{1}$, \\ Maria Cecília Afonso Fonseca ${ }^{1}$, Guilherme Araújo Lacerda ${ }^{1,2}$, Maria das Dores Magalhães Veloso ${ }^{1,2}$, \\ Arlete Barbosa dos Reis ${ }^{1,3}$, Márcio Antônio Silva Pimenta ${ }^{1,2}$ \& Sônia Ribeiro Arrudas ${ }^{1,2}$ \\ ${ }^{1}$ Universidade Estadual de Montes Claros, MG, Brazil \\ ${ }^{2}$ Departamento de Biologia Geral, Universidade Estadual de Montes Claros, MG, Brazil \\ ${ }^{3}$ Universidade Federal dos Vales do Jequitinhonha e Mucuri, Diamantina, MG, Brazil \\ Correspondence: Sônia Ribeiro Arrudas, Departamento de Biologia Geral, Universidade Estadual de Montes \\ Claros, MG, Brazil. E-mail: sonia.arrudas@unimontes.br
}

Received: September 9, 2021

doi:10.5539/jas.v13n12p27
Accepted: October 11, $2021 \quad$ Online Published: November 15, 2021

URL: https://doi.org/10.5539/jas.v13n12p27

\begin{abstract}
Soil pollution by highly toxic metals (such as lead, $\mathrm{Pb}$ ) derived from human activities has become a serious problem in recent years. Phytoremediation is a technique that uses plants or microorganisms to remedy such toxicity from contaminated soils and water. This study aimed to evaluate the efficiency of the legume Crotalaria juncea as a phytoremediator of lead-contaminated soils. We evaluated plant growth and lead content in the soil andin $C$. juncea's leaves and roots. Three treatments with varying concentrations of lead in the soil were evaluated: $0 \mathrm{mg} \mathrm{kg}^{-1}$ (control), $250 \mathrm{mg} \mathrm{kg}^{-1}$, and $500 \mathrm{mg} \mathrm{kg}^{-1}$. Plant growth and plant physical aspects were quantified. Metal concentration in the soil, leaves, and roots was assessed by atomic absorption spectrometry. The species had a survival rate of $100 \%$. The highest content of lead was found in the plants' roots. Plant growth did not differ significantly among the three treatments, leaf lead concentration did. Crotalaria juncea has potential for lead phytoremediator. In addition, it is a tolerant vegetal and hyperaccumulator of $\mathrm{Pb}$, mainly in the roots, and due to these characteristics its potential for phytoextraction of this metal under field conditions should be evaluated.
\end{abstract}

Keywords: metals, soil pollution, toxicity, lead, phytoremediator

\section{Introduction}

The soil suffers direct and indirect impacts from anthropogenic activities, including heavy metal, chemical product, andoil spills, which harm the environment and human populations (Heiderscheidt, Pereira, Burghardt, \& Oliveira, 2016). This type of contamination threatens human health, reduces water quality, and limits soil use in affected areas. When caused by heavy metals, these problems are particularly harmful due to their high toxicity (Santos \& Rodella, 2007). For instance, agricultural productivity is significantly reduced on heavy metal contaminated soils and, alarmingly, when absorbed by plants, these elements may enter the food chain (Nascimento et al., 2015).

Lead $(\mathrm{Pb})$ stands out among heavy metal soil contaminants (Souza et al., 2016). Although naturally found in the soil, its presence is exacerbated in areas associated with some human activities, which promotes social and environmental damage (Gratão, Prasad, Cardoso, Lea, \& Azevedo, 2005). A lot of effort has been made in recent years on the development of soil remediation techniques to minimize lead contamination impacts (Gabos, Abreu, \& Coscione, 2009; Ribeiro, 2015).

Phytoremediation has great potential to remove and degrade pollutants, transfer, destroy or stabilize elements considered harmful (Souza et al., 2016). Phytoremediation is an interesting alternative to restore contaminated sites (Xiao et al., 2008; Ali, Khan, \& Sajad, 2013). It involves several groups of mechanisms related to a plant's natural processes and its interaction with rhizosphere microorganisms, which altogether degrade, extract or immobilize organic and inorganic contaminants in soil and water (Ruby \& Appleton, 2010).

Species employed in phytoremediator can even colonize degraded soils where ecosystem productivity has been hindered by contamination (Andrade, Tavares, \& Mahler, 2007). 
The legume species Crotalaria juncea has high agricultural relevance. Among its benefits, the addition of nutrients to the soil (Santos, Silva, Carvalho, \& Caione, 2010) indicates its potential to improve soil quality. Because of its fast growth and soil enrichment, associated with biomass increase and nitrogen fixation (A. V. D. Araújo, E. F. Araújo, Amaro, Santos, \& Cecon, 2018), C. juncea is highly recommended for crop rotation (Sousa, 2011). The Crotalaria juncea leguminous species can improve nutrient cycling and chemical quality of soils, resulting in higher productivity of crops and are advantageous options for total accumulation of nutrients (Collier et al., 2018).

This study aimed to evaluate the efficiency of Crotalaria juncea as a phytoremediator of lead-contaminated soils by assessing its growth and lead content in leaves, roots and soil.

\section{Material Studied}

\subsection{Area Descriptions}

The experiment was conducted between September 2017 and February 2018. Seeds of Crotalaria juncea were grown in protected cultivation in greenhouses in the Center of Biological Sciences of the Estadual University of Montes Claros (UNIMONTES). Nine $8 \mathrm{~L}$ polyethylene vases were filled with locally collected cambissolo eutrophic halico soil (in the greenhouse area) in the proportion of 4,600 g soil to $400 \mathrm{~g}$ of humus. Holes were installed at the bottom of each vase for water drainage, because of the possibility it could be lead-contaminated.

\subsection{Methods and Techniques}

Three treatments with three repetitions were used in this study. Were mixed in plastic bags, the soil, humus and the contaminant $\mathrm{Pb}\left(\mathrm{NO}_{3}\right)_{2}$, lead nitrate solution, in different concentrations as described below, which were sealed and identified, and left to obtain a better homogenization for $24 \mathrm{~h}$. After, the seeds were planted $2 \mathrm{~cm}$ deep in the soil, 12 in each vase. After $7 \mathrm{~d}$, four plants remained in each vase. No corrective treatment was offered to the soil (fertilization and liming) and only humus was added, as described earlier. For lead addition, we used lead nitrate solution $\left(\mathrm{Pb}\left(\mathrm{NO}_{3}\right)_{2}\right)$ at different concentrations treatment: $0 \mathrm{mg} \mathrm{kg}^{-1}$ (treatment 1: control treatment; T1), $250 \mathrm{mg} \mathrm{kg}^{-1}$ (treatment 2; T2) and $500 \mathrm{mg} \mathrm{kg}^{-1}$ (treatment 3; T3). These concentrations were based on reference values provided by Resolution 420/2009, by the Brazilian National Environment Council. This resolution of the Brazilian legislation (CONAMA - National Council for Environmental Policy) quality of soil regarding the presence of chemical chemical substances and establishes guidelines for the management of areas contaminated by these substances as a result of anthropic activities. (CONAMA, 2009) (Table1).

Table 1. Reference values of soil lead concentration according to Resolution 420/2009 (CONAMA) - Brazilian legislation (National Council for Environmental Policy)

\begin{tabular}{llll}
\hline \multicolumn{3}{l}{ Soil $\left(\mathbf{m g ~ k g}^{-1}\right.$ of dry weight $)$} \\
\hline \multirow{2}{*}{ Prevention $\left(\mathbf{m g ~ k g}^{-\mathbf{1}}\right)$} & \multicolumn{3}{c}{ Investigation } \\
\cline { 2 - 4 } & Agricultural MaxPA & Residential & Industrial \\
\hline 72 & 180 & 300 & 900 \\
\hline
\end{tabular}

Note. MaxPA: Maximum protection area.

To ensure that suitable water for plant development was provided, water was added and soil humidity was monitored daily. Plant growth was monitored weekly from September to January using a graded ruler. Wilting and yellowing were also monitored.

Physical-chemical soil analysis was done in the Laboratory of Soil Analysis of the Federal University of Minas Gerais (UFMG-ICA). In each monitoring month, leaf samples were collected and washed in running distilled water, detergent solution $(0.1 \%)$, and deionized water. They were then divided into fragments of approximately $20 \mathrm{~mm}$ and oven-dried in an air-circulation heating furnace at an average temperature of $65{ }^{\circ} \mathrm{C}$ for 72 hours (Masdor, Izuan, Baskaramn, \& Sulaiman, 2014). Samples were macerated and stored dried in beakers.

To assess the presence and concentration of lead in the samples, employed the overnight method for sample digestion (Rashid et al., 2016), conducted in the Agrochemical Research Laboratory in the UFMG-ICA. Soil and leaf samples underwent this procedure every $30 \mathrm{~d}$ for three months (November, December, and January), while root samples were only analyzed once, in the last month of analysis (January). For the soil and leaves, added 10 $\mathrm{mL}$ of nitric acid to each $\mathrm{g}$ of sample, while for the roots, added $10 \mathrm{~mL}$ of nitric acid to each $0.5 \mathrm{~g}$ of sample. Each sample was enclosed with a glass funnel and left overnight for pre-digestion in the fume hood. The 
following day, the samples were heated and digested for gas extraction on a heating plate $\left(90-120^{\circ} \mathrm{C}\right)$. The extracts were filtered and recovered in $25 \mathrm{mLvolumetric}$ flasks with ultrapure water.

To generate the analytical curve $\left(0.5\right.$ to $\left.8.0 \mathrm{mg} \mathrm{L}^{-1}\right)$, we used different concentrations of standard lead $(\mathrm{Pb})$ solution in ultrapure water (Milli-q) for atomic absorption spectroscopy (Sigma-Aldrich, Germany). Lead concentration was analyzed in an absorption spectrophotometer (Varian, AA240FS). Used an air-acetylene flame for lead atomization (acetylene with a purity of 99.999\%). The treatments were performed in triplicates. Performed an analysis of variance (two-way ANOVA) to assess significance and used Bonferroni test at 5\% for comparisons.

\section{Results}

The results of soil characterization are presented in Tables 2 and 3 respectively. The concentration of lead in the soil was $30.70 \mathrm{mg} \mathrm{kg}^{-1}$.

Table 2. Physical characterization of the soil sample

\begin{tabular}{ll}
\hline Soil attributes & Concentration $\left(\mathbf{d a g} \mathbf{~ k g}^{-1}\right)$ \\
\hline Coarse sand & 44.30 \\
Fine sand & 23.70 \\
Silt & 18.00 \\
Clay & 14.00 \\
\hline
\end{tabular}

Table 3. Chemical characterization of the soil sample

\begin{tabular}{lll}
\hline Soil attributes & Unit & Concentration \\
\hline Phosphorous (P) & $\mathrm{mg} \mathrm{dm}^{-3}$ & 135.0 \\
Potassium (K) & $\mathrm{mg} \mathrm{dm}^{-3}$ & 101.0 \\
Calcium (Ca) & $\mathrm{cmolc} \mathrm{dm}^{-3}$ & 9.37 \\
Magnesium (Mg) & $\mathrm{cmolc} \mathrm{dm}^{-3}$ & 4.07 \\
Aluminum(Al) & $\mathrm{cmolc} \mathrm{dm}^{-3}$ & 0.00 \\
$\mathrm{H}+\mathrm{Al}$ & $\mathrm{cmolc} \mathrm{dm}^{-3}$ & 1.57 \\
Organic matter & $\mathrm{dag} \mathrm{kg}^{-1}$ & 5.58 \\
\hline
\end{tabular}

The plants were kept in the soil for $110 \mathrm{~d}$. Some reached the flowering stage around $60 \mathrm{~d}$ after sowing. Crotalaria juncea plants had a survival rate of $100 \%$, i.e., no plants died throughout the 110 days trial. C. juncea seeds germinated both in the presence and in the absence of lead. According to Figure 1, plant development (growth) did not differ significantly among treatments $(\mathrm{P}<0.0001)$.

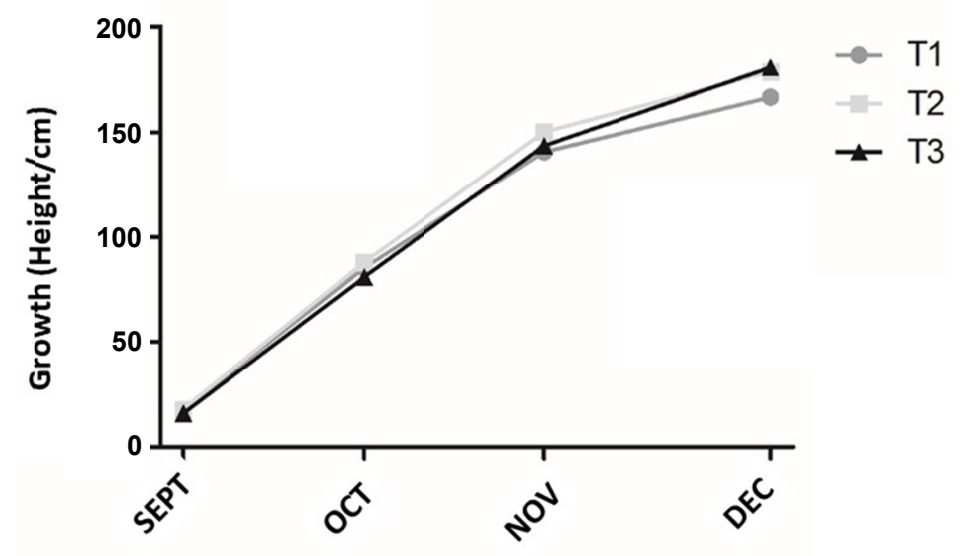

Figure 1. Growth of Crotalaria juncea per 4 month analyzed: T1: control treatment; T2: addition of $250 \mathrm{mg} \mathrm{kg}^{-1}$ of $\mathrm{Pb}$, T3: addition of $500 \mathrm{mg} \mathrm{kg}^{-1}$ of $\mathrm{Pb}$ 
In terms of physical aspects, plants from all treatments presented leaf loss, leaf spots, and leaf curling withchlorosis. These effects were more evident in $\mathrm{T} 3$.

Table 4. Lead concentration in the Crotalaria juncea leaves (averages and standard deviations)

\begin{tabular}{|c|c|c|c|c|}
\hline & \multirow{2}{*}{ Treatments } & \multicolumn{3}{|c|}{ Concentration Leaf $\left(\mathrm{mg} \mathrm{kg}^{-1}\right)$} \\
\hline & & Nov & Dec & Jan \\
\hline \multirow{3}{*}{ Leaf } & $\mathrm{T} 1$ & $14.307 \pm 0.019$ & $14.153 \pm 0.400$ & $14.510 \pm 0.016$ \\
\hline & $\mathrm{T} 2$ & $25.333 \pm 0.034$ & $15.333 \pm 0.169$ & $15.377 \pm 0.092$ \\
\hline & $\mathrm{T} 3$ & $21.517 \pm 0.040$ & $16.4531 \pm 0.030$ & $13.990 \pm 0.014$ \\
\hline
\end{tabular}

Note. T1: control treatment; T2: addition of $250 \mathrm{mg} \mathrm{kg}^{-1} \mathrm{of} \mathrm{Pb}$; T3: addition of $500 \mathrm{mg} \mathrm{kg}^{-1} \mathrm{of} \mathrm{Pb}$.

Results related lead Concentration in Crotalaria juncea to root lead absorption is shown in Table 5.

Table 5. Lead concentration in Crotalaria juncea roots (averages and standard deviation observed in January)

\begin{tabular}{lll}
\hline & Treatments & Concentration $\left(\mathbf{m g ~ k g}^{-\mathbf{1}}\right)$ \\
\hline \multirow{3}{*}{ Root } & $\mathrm{T} 1$ & $24.713 \pm 0.280$ \\
& $\mathrm{~T} 2$ & $95.000 \pm 0.216$ \\
& $\mathrm{~T} 3$ & $212.467 \pm 1.342$ \\
\hline
\end{tabular}

Figure 2 presents lead absorption by $C$. juncea leaves, which differed significantly between months and treatments $(\mathrm{P}<0.0001)$, Highlighting the presence of lead even in the soils from the control treatment.

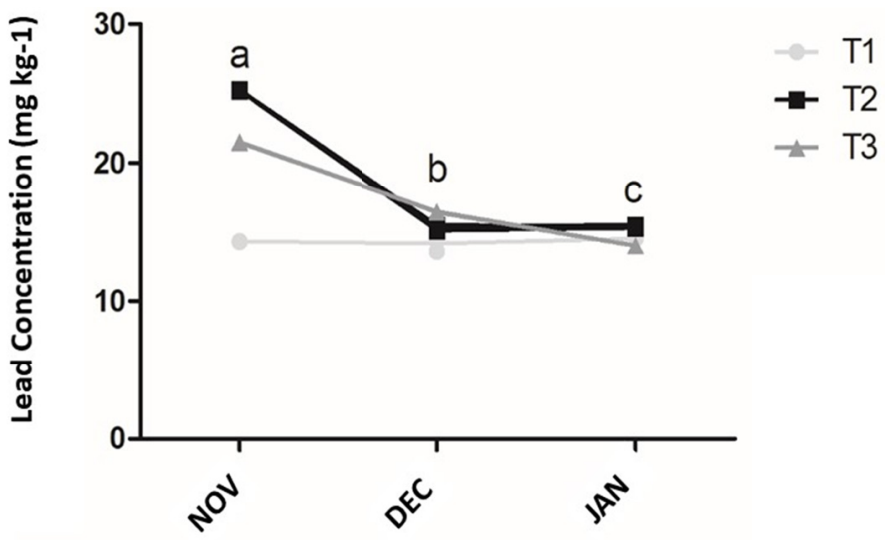

Figure 2. Lead concentration in Crotalaria juncea leaves in the months analyzed: T1: control treatment; T2: addition of $250 \mathrm{mg} \mathrm{kg}^{-1}$ of $\mathrm{Pb}$; T3: addition of $500 \mathrm{mg} \mathrm{kg}^{-1} \mathrm{of} \mathrm{Pb}$

Found higher concentrations of lead in the roots than in the aerial parts of Crotalaria juncea plants, evidencing the intense accumulation of lead in the subterranean part of the plant (Table 5).

\section{Discussion}

Seed germination is an essential step for plant development in contaminated soils and helps to evaluate plant tolerance to a given contaminant (Di Salvatore, Carafa, \& Garratu, 2008). Here, the legume Crotalaria juncea was analyzed on lead-contaminated soils and showed constant germination in all treatments. This was unlike previous results for lettuce (M. P. Pereira, F. J. Pereira, Rodrigues, Barbosa, \& Castro, 2013), whereby germination was inversely proportional to lead concentration.

Other than germination, plant growth on heavy metal contaminated soilsis also used as an indicator of plant tolerance (L. A. Souza, Andrade, S. C. R. Souza, \& Schiavinato, 2011). Crotalaria juncea plants displayed constant growth in all treatments throughout the monitoring period (Figure 1). This was unlike previous results for Ricinus communis L (whereby growth was inversely proportional to lead concentration in the soil) (Santos, 
Garcia, Colonego, Sposito, \& Rigolin, 2012), but similar to studies with Carex rostrata, Eriophorum angustifolium, Phragmites australis and Canavalia ensiformes (all of which showed similar growth across different lead concentrations in the soil) (Stoltz \& Greger, 2002; Almeida, Marcos, Schiavinato, Lagoa, \& Abreu, 2008). Plants share a common ability to prolong survival when in contact with excessive trace elements in their environments (Kabata-Pendias \& Pendias, 2000).

The Resolution 420/2009 by the Brazilian National Environment Council (CONAMA, 2009) provided objective criteria to assess soil quality in the presence of chemical substances and establishes guidelines for environmental management of contaminated areas as a result of human activities. It presents specific concentration values of chemical compounds and associated alterations in soil and groundwater. The parameters used are determined by statistical interpretations of physical-chemical analyses of different soil types and are thus defined:

Value of Prevention (VP): Concentration threshold of a given substance in the soil at which the soil is able to maintain its main functions. Value of Investigation (BI): Concentration of a given substance in soil or groundwater above which potential, direct or indirect risks to human health arise, given a standardized exposures cenario.

Although we detected lead in the soil used in the experiment (as described in the Results section), its concentration at $30.0 \mathrm{mg} \mathrm{kg}^{-1}$ is below the value of prevention and, therefore, does not raise concerns.

The physical aspects observed in $C$. juncea plants (leaf loss, leaf spots, and leaf curling with chlorosis) could be symptoms of nutrient deficiency, since the soil was not corrected as mentioned by Lindino, Tomczac, and Gonçalves Junior (2012). None of the plants died, despite these symptoms, which suggests resistance by $C$. juncea. The plants under the treatment with the highest lead concentration (T3) displayed most of these aspects. The most common among them was leaf yellowing (which is caused by low chlorophyll levels), sometimes followed by plant degeneration (Alvarenga, Araújo, \& Silva, 1998).

Lead accumulation in $C$. juncea leaves (Table 4) suggested high tolerance of this species to lead. Its concentration was below what is considered toxic for plants $\left(30-300 \mathrm{mg} \mathrm{kg}^{-1}\right)$ (Kabata-Pendias \& Pendias, 2000).

In the first month of monitoring, identified lead absorption by the leaves with a subsequent decrease and stabilization in the following months, suggesting a saturation limit and possibly the use of lead in C. crotalaria's metabolic processes (Figure 2). Romeiro, Lagôa, Furlani, Abreu, and Pereira (2007) investigated the content of lead in the aerial part of plants and found a low coefficient of determination, showing that increasing lead addition to the soil did not result in a proportional increase in lead concentration in their aerial parts.

Lead is an easily absorbed and accumulated element in different parts of the plants (Sharma \& Dubey, 2005). Results showed that the highest concentration of lead, among different parts of $C$. juncea plants, was found within the roots (Table 5). This result agrees with those found in other plant species, such as Cedrela fissilis, Handroanthus impetignosus, Copaifera langsdorffii, Hymenaea courbaril, Mimosa caesalpiniifolia and Acacia mangium (Marques, Siqueira, \& Moreira, 2000; Soares, Accioly, Marques, Siqueira, \& Moreira, 2001; Piechalak, Tomaszewska, Baralkiewicz, \& Malecka, 2002; Paiva, Carvalho, Siqueira, Fernandes, \& Miranda, 2003). Alves et al. (2008), who evaluated the tolerance, absorption and distribution of lead in plants, also found higher lead absorption in the roots of vetiver (Vetiveria zizanioides (L.) Nash), desmanthus (Desmanthus virgatus (L.) Willd), and a species of mesquite (Prosopis juliflora (SW) DC). Metal translocation from the roots to the aerial parts of a plant involves a long process of xylem translocation until the storage of the element inside the leaf cell vacuole. This process is influenced by many different factors, such as soil type, fertilization (or lack thereof), mode of fertilization, and level of nutrient addition (Kabata-Pendias \& Pendias, 2000).

The lead absorption rate by Crotalaria juncea plants allowed to observe the potential metal accumulation by its aerial and underground parts. In general, the plant was able to accumulate the metal not only in its roots, where the concentration was highest, but also in its aerial parts. However, the absorption rate showed that lead absorption by Crotalaria juncea is not proportional to lead addition. The highest $\mathrm{Pb}$ concentration and content were found in all compartments of Crotalaria juncea, which suggests a high potential of this plant for phytoremediation of $\mathrm{Pb}$-contaminated areas.

Different aspects can be considered to evaluate the potential of a species to phytoremediate contaminated soils. Plants hyperaccumulating $\mathrm{Pb}$ are those capable of extracting and accumulating in their tissues values higher than $1,000 \mathrm{mg} \mathrm{kg}^{-1}$ of $\mathrm{Pb}$ in dry mass (Raskin et al. 1994). In relation to the values found in this study, it can be inferred that the Crotalaria Juncea plants, besides being tolerant to $\mathrm{Pb}$, have characteristics of hiperaccumulators. Lead obtention by plants involves root absorption and transportation to the leaves. Bettiol and Camargo (2000) reported that lead solubilization by root exudates is an important absorption mechanism by plants. In summary, 
lead is obtained through root absorption, storage in leaf walls and limited transference to the plant's aerial part (Garbisu \& Alkorta, 2001).

\section{Conclusion}

Crotalaria juncea has potential for phytoremediation of lead-contaminated soils. To better understand this potential, future research should investigate the as yet little explored metabolic processes of lead uptake by $C$. juncea plants. In addition, it is a tolerant vegetal and hyperaccumulator of $\mathrm{Pb}$, mainly in the roots, and due to these characteristics its potential for phytoextraction of this metal under field conditions should be evaluated.

\section{Acknowledgements}

The authors would like to thank the Estadual University of Montes Claros (UNIMONTES), and the GEPAEQ-Group of Studies and Research Appliedto Chemical Engineering at UFVJM-Federal University of Vales do Jequitinhonha and Mucuri-Diamantina-MG/Brazil.

\section{References}

Ali, H., Khan, E., \&Sajad, M. A. (2013). Phytoremediation of heavy metals-Concepts and application. Chemosphere, 7, 869-881. https://doi.org/10.1016/j.chemosphere.2013.01.075

Almeida, E. L., Marcos, F. C. C., Schiavinato, M. A., Lagoa, A. M. M. A., \& Abreu, M. F. (2008). Crescimento de feijão de porco na presença de chumbo. Bragantia, 67(3), 569-576. https://doi.org/10.1590/S0006-870 52008000300003

Alvarenga, P., Araújo, P. F., \& Silva, J. A. (1998). As Plantas, os Solos, os Metais e a Vida-Jogos Múltiplos. Boletim da Sociedade Portuguesa de Química, 71, 10-19. https://doi.org/10.52590/M3.P595.A3000856

Alves, J. C., Souza, A. P., Pôrto, M. L., Arruda, J. A., Tompson Junior, U. A., Silva, G. B., \& Santos, D. (2008). Absorção e distribuição de chumbo em plantas de vetiver, jureminha e algaroba. Revista Brasileira de Ciência do Solo, 32(3), 1329-1336. https://doi.org/10.1590/S0100-06832008000300040

Andrade, J. C. M., Tavares, S. R. L., \& Mahler, C. F. (2007). Fitorremediação: o uso de plantas na melhoria da qualidade ambiental. São Paulo: Oficina de Textos-Brasil.

Araújo, A. V. D., Araújo, E. F., Amaro, H. T. R., Santos, R. H. S., \&Cecon, P. R. (2018). Time of harvest and storability of Crotalaria juncea L. seeds. Revista Ciência Agronômica, 49(1), 103-111. https://doi.org/ $10.5935 / 1806-6690.20180012$

Bettiol, W., \& Camargo O. A. (2000). Impacto ambiental do uso agrícola do lodo de esgoto (pp. 249-259). Jaguariúna: EMBRAPA.

Collier, L. S., Arruda, E. M., Campos, L. F. C., \& Nunes, J. N. V. (2018). Soil chemical attributes and corn productivity grown on legume stubble in agroforestry systems. Rev. Caatinga, 31(2), 279-289. https://doi.org/10.1590/1983-21252018v31n203rc

CONAMA (Conselho Nacional do Meio Ambiente). (2009). Dispõe sobre critérios e valores orientadores de qualidade do solo quanto à presença de substâncias químicas e estabelece diretrizes para o gerenciamento ambiental de áreas contaminadas por essas substâncias em decorrência de atividades antrópicas (Resolução No 420, de 28 de Dezembro de 2009).

Di Salvatore, M., Carafa, A. M., \& Garratù, G. (2008). Assessment of heavy metals phytotoxicity using seed germination and root elongation tests: A comparison of two growth substrates. Chemosphere, 73(9), 1461-1464. https://doi.org/10.1016/j.chemosphere.2008.07.061

Gabos, M. B., Abreu, C. A., \& Coscione, A. R. (2009). EDTA assisted phytorremediation of a Pb contaminated soil: Metal leaching and uptake by Jack beans. Scientia Agricola, 66(4), 506-514. https://doi.org/10.1590/ S0103-90162009000400012

Garbisu, C., \& Alkorta, I. (2001). Phytoextraction: A cost-effective plant-based technology for the removal of metals from the environment. Bioresource Technology, 77(3), 229-236. https://doi.org/10.1016/S0960-8524 (00)00108-5

Gratão, P. L., Prasad, M. N. V., Cardoso, P. F., Lea, P. J., \& Azevedo, R. A. (2005). Phytoremediation: Green technology for the cleanup of toxic metals in the environment. Brazilian Journal of PlantPhysiology, 17(1), 53-64. https://doi.org/10.1590/S1677-04202005000100005

Heiderscheidt, D., Pereira, J., Burghardt, J. E., \& Oliveira, S. C. (2016). Conceitos aplicados à poluição do solo decorrente do derrame de petróleo e seus derivados. Revista Maiêutica, 4(1), 7-14. 
Kabata-Pendias, A., \& Pendias, H. (2000). Trace elements in soils and plants (3rd ed.). Boca Raton: CRC Press. https://doi.org/10.1201/9781420039900

Lindino, C. A., Tomczac, A. P., \& Gonçalves Junior, A. C. (2012). Fitorremediação de solos utilizando Crotalaria spectabilis para remoção de cádmio e chumbo. Scientia Agraria Paranaensis, 11(4), 25-32. https://doi.org/10.18188/sap.v11i4.5720

Marques, T. C. L. S. M., Siqueira, J. O., \& Moreira, F. M. S. (2000). Crescimento e teor de metais de mudas de espécies arbóreas cultivadas em solo contaminado com metais pesados. Pesquisa Agropecuária Brasileira, 35(1), 121-132. https://doi.org/10.1590/S0100-204X2000000100015

Masdor, N. A., Izuan, E. H., Baskaramn, G., \& Sulaiman, R. (2014). Screening of Heavy Metals in Selected Vegetables using the Papain Inhibitive Assay. Asian Journal of PlantBiology, 2(6), 28-31.

Nascimento, A. L., Junio, G. R. Z., Sampaio, R. A., Fernandes, L. A., Carneiro, J. P., \& Barbosa, C. F. (2015). Metais pesados no solo e mamoneira adubada com biossólido e silicato de cálcio e magnésio. Revista Brasileira de Engenharia Agrícola e Ambiental, 19(5), 505-511. https://doi.org/10.1590/1807-1929/ agriambi.v19n5p505-511

Paiva, H. P., Carvalho, J. G., Siqueira, J. O., Fernandes, A. R., \& Miranda, J. R. P. (2003). Influência de doses crescentes de chumbo sobre o teor e o conteúdo de nutrientes e de $\mathrm{Pb}$ em mudas de ipê-roxo (Tabebuia impetiginosa (Mart.) Standl.). Revista Árvore, 27(2), 151-158. https://doi.org/10.1590/S0100-67622003000 200005

Pereira, M. P., Pereira, F. J., Rodrigues, L. C. A., Barbosa, S., \& Castro, E. M. (2013). Fitotoxicidade do chumbo na germinação e crescimento inicial de alface em função da anatomia radicular e ciclo celular. Revista Agro@mbiente On-Line, 7(1),36-43. https://doi.org/10.18227/1982-8470ragro.v7i1.895

Piechalak, A., Tomaszewska, B., Baralkiewicz, D., \& Malecka, A. (2002). Accumulation and detoxification of lead ions in legumes. Phytochemistry, 60(2), 153-162. https://doi.org/10.1016/S0031-9422(02)00067-5

Rashid, M. H., Fardous, Z., Chowdhury, M. A. Z., Alam, M. K., Bari, M. L., Moniruzzaman, M., \& Gan, S. H. (2016). Determination of heavy metals in the soils of tea plantations and in fresh and processed tea leaves: An evaluation of six digestion methods. Chemistry Central Journal, 10, Article Number 7. https://doi.org/ 10.1186/s13065-016-0154-3

Raskin, I., Kumar, P. N., Dushenkov, J. R., \& Salt, D. E. (1994). Bioconcentration of heavy metals by plants. Current Opinions Biotechnology, 5, 285-290. https://doi.org/10.1016/0958-1669(94)90030-2

Ribeiro, E. S., Pereira, M. P., Castro, E. M., Baroni, G. R., Corrêa, F. F., \& Pereira, F. J. (2015). Relações da anatomia radicular na absorção, no acúmulo e na tolerância ao chumbo em Echinodorus grandiflorus. Revista Brasileira de Engenharia Agricola e Ambiental, 19(6), 605-612. https://doi.org/10.1590/1807-1929/ agriambi.v19n6p605-612

Romeiro, S., Lagôa, A. M. A., Furlani, P. R., Abreu, C. A., \& Pereira, B. F. F. (2007). Absorção de chumbo e potencial de fitorremediação de Canavalia ensiformes L. Bragantia, 66(2), 327-334. https://doi.org/ $10.1590 / \mathrm{S} 0006-87052007000200017$

Ruby, M., \& Appleton, B. (2010). Using landscape plants for phytoremediation. Low Impact Development International Conference. ASCE Library. https://doi.org/10.1061/41099(367)29

Santos, C. H., Garcia, A. L. O., Colonego, J. C., Sposito, T. H. N., \& Rigolin, I. M. (2012). Potencial de fitoextração de $\mathrm{Pb}$ por mamoneiras em solo contaminado. Semina: Ciências Agrárias, 33(4), 1427-1434. https://doi.org/ 10.5433/1679-0359.2012v33n4p1427

Santos, G. C. G., \& Rodella, A. A. (2007). Efeitos da adição de fontes de matéria orgânica como amenizantes do efeito tóxico de $\mathrm{B}, \mathrm{Zn}, \mathrm{Cu}, \mathrm{Mn}$ e Pb no cultivo de Brassica juncea. Revista Brasileira de Ciência do Solo, 31, 793-804. https://doi.org/10.1590/S0100-06832007000400019

Santos, P. A., Silva, A. F., Carvalho, M. A. C., \& Caione, G. (2010). Adubos verdes e adubação nitrogenada em cobertura no cultivo do milho. Revista Brasileira de Milho e Sorgo, 9(2), 123-34. https://doi.org/10.18512/ 1980-6477/rbms.v9n2p123-134

Sharma, P., \& Dubey, R. S. (2005). Lead toxicity in plants. Brazilian Journal of Plant Physiology, 17(1), 35-52. https://doi.org/10.1590/S1677-04202005000100004

Soares, C. R. F. S., Accioly, A. M. A., Marques, T. C. L. S. M., Siqueira, J. O., \& Moreira, F. M. S. (2001). Acúmulo e distribuição de metais pesados nas raízes, caule e folhas de mudas de árvores em solo 
contaminado por rejeito de indústria de zinco. Revista Brasileira de Fisiologia Vegetal, 13(3), $302-315$. https://doi.org/10.1590/S0103-31312001000300006

Sousa, G. M. M. (2011). Adubação orgânica e densidades de plantas em Crotalaria juncea antecedendo arroz (Master's thesis, Universidade Federal Rural do Semi-Árido, Mossoró, Brazil). Retrieved from http://repositorio.ufersa.edu.br/handle/tede/470

Souza, L. A., Andrade, S. A. L., Souza, S. C. R., \& Schiavinato, M. A. (2011). Tolerância e potencial fitorremediador de Stizolobium aterrimum associada ao fungo micorrízico arbuscular Glomusetunicatum em solo contaminado por chumbo. Revista Brasileira de Ciência do Solo, 35(4), 1441-1451. https://doi.org/ 10.1590/S0100-06832011000400038

Souza, V., Konrad, O., \& Gonçalves Junior, A. C. (2016). Contaminação por chumbo, riscos, limites legais e alternativas de remediação. Veredas do Direito, 13(25), 249-276. https://doi.org/10.18623/rvd.v13i25.643

Stoltz, E., \& Greger, M. (2002). Accumulation properties of As, Cd, Cu, Pb and $\mathrm{Zn}$ by four wetland plant species growing on submerged mine tailing. Environmental and Experimental Botany, 47(3), 271-280. https://doi.org/10.1016/S0098-8472(02)00002-3

Xiao, X., Chen, T., An, Z., Lei, M., Huang, Z., Liao, X., \& Liu, Y. (2008). Potential of Pterisvittata L. for phytorremediation of sitios co-contaminated with cadmium and arsenic: The tolerance and accumulation. Journal of Environmental Sciences, 20(1), 62-67. https://doi.org/10.1016/S1001-0742(08)60009-1

\section{Copyrights}

Copyright for this article is retained by the author(s), with first publication rights granted to the journal.

This is an open-access article distributed under the terms and conditions of the Creative Commons Attribution license (http://creativecommons.org/licenses/by/4.0/). 